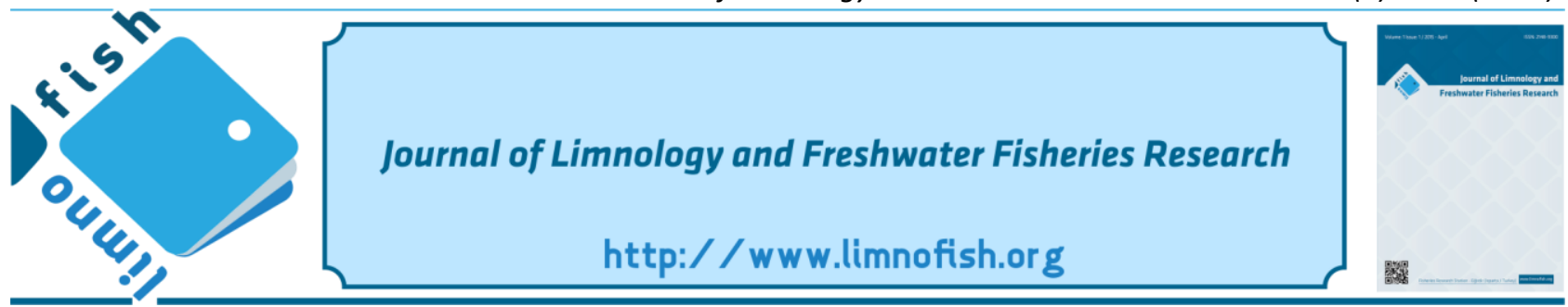

\title{
Effects of Temperature Changes on the Spatial Distribution and Ecology of Ostracod (Crustacea) Species
}

\author{
Derya AKDEMIR ${ }^{*}$ (iD), Okan KÜLKÖYLÜOĞLU² (iD \\ ${ }^{1}$ Institute of Geology and Mineralogy, University of Cologne, 50674, Köln, Germany \\ ${ }^{2}$ Department of Biology, Faculty of Arts and Science, Bolu Abant İzzet Baysal University, 14280, Bolu, Turkey
}

\section{A B STR ACT}

To understand the possible effects of changes in ambient temperature on spatial distribution and ecology of ostracods, samples were randomly collected from 70 aquatic sites with 12 different habitat types from Hatay (Turkey) province during the summer season of 2012. 14 of 19 ostracod species were newly reported for the province. The first two axes of CCA explained $79.7 \%$ of the cumulative variance of the relationship between the 12 most common species and five environmental variables. Accordingly, water temperature and electrical conductivity were the most effective factors on species occurrences $(p<0.05)$. Estimating ecological optimum and tolerance values of species revealed that Herpetocypris chevreuxi and Cypridopsis vidua displayed the lowest and highest tolerance values for water temperature, respectively. TWINSPAN results illustrated that ostracod species can be used to determine characteristics of habitat conditions. Indeed, the co-occurrence of $H$. chevreuxi with one or more cosmopolitan species is the indication of an increase in salinity and temperature values. Results suggested that temperature changes can cause critical alteration in shallow water bodies where species with lower ecological tolerances will eventually be negatively affected. Therefore, such species, which may be called "potential candidate species for local extinction" will either be eliminated from the habitats in short term or become extinct in long term.

\section{ARTICLE INFO}

\section{RESEARCH ARTICLE}

Received : :06.07.2020

Revised : :21.09.2020

Accepted : 22.09 .2020

Published : 29.04.2021

DOI:10.17216/LimnoFish.765049

\section{* CORRESPONDING AUTHOR}

dakdemir@uni-koeln.de

Phone : 00492214705784

Keywords: Ecology, Ostracoda, indicator species, local extinction, Turkey

\section{Sıcaklık Değişimlerinin Ostrakod (Crustacea) Türlerinin Mekansal Dağılımı ve Ekolojisi Üzerine Etkisi}

Öz: Ortam sıcaklığındaki değişimlerin ostrakodların mekansal dă̆ılımı ve ekolojisi üzerindeki olası etkilerini anlamak için, 2012 yazında Hatay (Türkiye) ilinden 12 farklı habitat türüne sahip 70 su sahasından rastgele örnekler toplanmıştır. Elde edilen 19 türden 14 tanesi Hatay için yeni kayıttır. CCA'nın ilk iki ekseni en yaygın 12 tür ile beş çevresel değişken arasındaki ilişkinin toplam varyansının \%79,7'sini açıklamıştır. Buna göre, su sıcaklığı ve elektriksel iletkenlik türlerin oluşu üzerinde en etkili faktörlerdir $(\mathrm{p}<0,05)$. Türlerin ekolojik optimum ve tolerans değerlerine göre, Herpetocypris chevreuxi ve Cypridopsis vidua su sıcaklığ 1 için sırasıyla en düşük ve en yüksek tolerans değerlerini göstermiştir. TWINSPAN sonuçları, ostrakod türlerinin habitat koşullarının özelliklerini belirlemek için kullanılabileceğini göstermiştir. Özellikle $H$. chevreuxi'nin bir veya daha fazla kozmopolit türle birlikte bulunması, tuzluluk ve sıcaklık değerlerinde bir artışın göstergesidir. Sonuçlar, özellikle sı̆̆ su kütlelerinde kritik değişikliğe neden olabilen sıcaklık değişiklikleri nedeniyle düşük ekolojik toleranslı türlerin olumsuz etkileneceğini düşündürmektedir. Bu nedenle, "yerel yok olma için potansiyel aday türler" olarak adlandırılabilecek bu türler ya kısa dönemde habitatlardan elenecek ya da uzun dönemde nesli tükenme tehlikesiyle karşı karşıya kalacaktır.

Anahtar kelimeler: Ekoloji, Ostracoda, gösterge tür, yerel yok olma, Türkiye

\section{How to Cite}

Akdemir D, Külköylüoğlu O. 2021. Effects of Temperature Changes on the Spatial Distribution and Ecology of Ostracod (Crustacea) Species. LimnoFish. 7(1): 1-13. doi: 10.17216/LimnoFish.765049

\section{Introduction}

Extinction is not one inevitable result that organisms must face. However, it is a fact that most (if not all) species are under the threat of global and/or local extinction (Black et al. 2001; Eisenhauer et al. 2019) due to climatic and anthropogenic factors. The loss of biodiversity is especially noticeable in freshwater ecosystems. Because, cumulative effects of climate change and human-induced factors (e.g., land-use change, destruction, overexploitation) cause 
changing in flow regime and chemical composition of freshwaters (Dudgeon et al. 2006; Ertürk 2012; Leigh 2013). Consequently, this situation leads to critical alteration in species composition in a habitat and/or geographic distribution of species (An et al. 2013; Finlayson et al. 2013). Because, when species are faced with changes, most (if not all) of them will not be able to develop fast responses enough to the new environmental conditions. While the species may have a chance to survive as they fit the new conditions by different adaptation abilities, the others, which have restricted ecological ranges, may either become more vulnerable or die out.

Invertebrate animals, playing an important role in the continuous function of ecosystems, are examples of facing threats of extinction or rapid decline in their numbers (Benateau et al. 2019). Indeed, examples of human effect coped with local climatic factors have been illustrated in aquatic habitats along with rapid loss of invertebrates. For example, levels of response to climate change conditions were found various among different benthic invertebrates and four ecoregions in 26 European streams and rivers (Jourdan et al. 2018). Of which, an abundance of sensitive Plecoptera was declined during warmer years while the abundance of Ephemeroptera was increased in northern regions. Besides, Jourdan et al. (2018) found a significant increase in the abundance of invasive species with an increasing number of harsh days induced by climatic changes.

Of invertebrates, Ostracods (Ostracoda: Crustacea) are one of the diverse and abundant taxonomic groups with about 65000 fossil and living species (Kempf 1980, 1997). There are about 2300 subjective non-marine species distributed worldwide (Meisch et al. 2019). They are also an important element in the food chain in shallow aquatic bodies (Mesquita-Joanes et al. 2012) and work as key species on production and community metabolism of micro- or mesocosm freshwater beds (Ruiz et al. 2013). Having with wide global distribution in a variety of aquatic habitats, ostracods are considered to provide supportive evidence for environmental changes because of their speciesspecific habitat preferences and different levels of ecological tolerance and optimum ranges.

Combining developing technology with historical and palaeoclimatological data can help to produce future climate change scenarios. Accordingly, different future climate estimation models showed that the climate of the world with an increase in temperature and a shift in precipitation patterns has already changed (IPCC 2007). In Turkey, mean air temperature is foreseen to increase between $1{ }^{\circ} \mathrm{C}-2^{\circ} \mathrm{C}$ in $2016-2040$ and $1.5^{\circ} \mathrm{C}-4^{\circ} \mathrm{C}$ in 2041-2070, while rainfall trends are less predictable with possible increases and decreases in average precipitation rates (Demircan et al. 2017). Ragab and Prudhomme (2002) projected that amount of precipitation will decrease, and temperature will increase by about $1.75-2.5^{\circ} \mathrm{C}$ by the year 2050 for the Mediterranean region. In potent climate fluctuations especially the precipitation changes, in some areas such as the Mediterranean region of Anatolia where our study area Hatay province is located, is one of the susceptible areas in Turkey (Karabulut 2009).

Aside from these, Hatay province was chosen as a study area since there has been no spatially extensive and comprehensive study asking the relationship between temperature changes and their effect on ostracod assemblages. Hence, this study aimed to (i) investigate correlation between the effects of ecological changes (e.g., temperature) and distribution of individual ostracod species, and (ii) estimate species ecological tolerance and optimum values along with determining their indicator values.

\section{Materials and Methods}

Hatay province with a surface area of $5403 \mathrm{~km}^{2}$ is bordered by Syria and the Mediterranean Sea on the south-eastern and western sites, respectively (Figure 1). Having with İskenderun and Antakya ports, it is one of the heavily industrialized districts on the Mediterranean coast. Besides, organized industrial zones located around the sea, freshwater, and terrestrial ecosystems have negative effects on natural sources in its environment. Because of its location in the southern part of Turkey, the city is under the influence of the Mediterranean climate characterized by very hot, long, and dry summers with cool rainy winters. Samples were randomly collected from 12 different inland water bodies (lake, dam, pond, pool, trough, ditch, irrigation canal, creek, stream, river, waterfall, and spring) in 70 sites located at about sea level $(11 \mathrm{~m})$ to $740 \mathrm{~m}$ a.s.l of elevations. Since July and August are the hottest months of the region, we thought that sampling between 31 July and 7 August 2012 might be better to show the utmost effect of the air temperature on water bodies. Thus, materials were collected with a plankton hand net ( $200 \mu \mathrm{m}$ in mesh size) from each site and stored in $250 \mathrm{ml}$ of a plastic container with $70 \%$ ethanol. Then, the material was filtered over four standard sieves $(1.5,1.0,0.5$, and $0.25 \mathrm{~mm})$ and ostracods separated from sediment with fine needles under the Meiji-Techno stereo microscope in the laboratory. Species description was done based on soft body parts and carapace, which are dissected and preserved in Lactophenol - Orange G solution, under the Olympus CX-41 light microscope by using different taxonomic works (Broodbakker and Danielopol 1982; Karanovic 2006, 2012; 
Meisch 1984, 1985, 2000). All forms of the species Abant İzzet Baysal University, Bolu, are preserved at the Limnology Laboratory of Bolu Turkey.

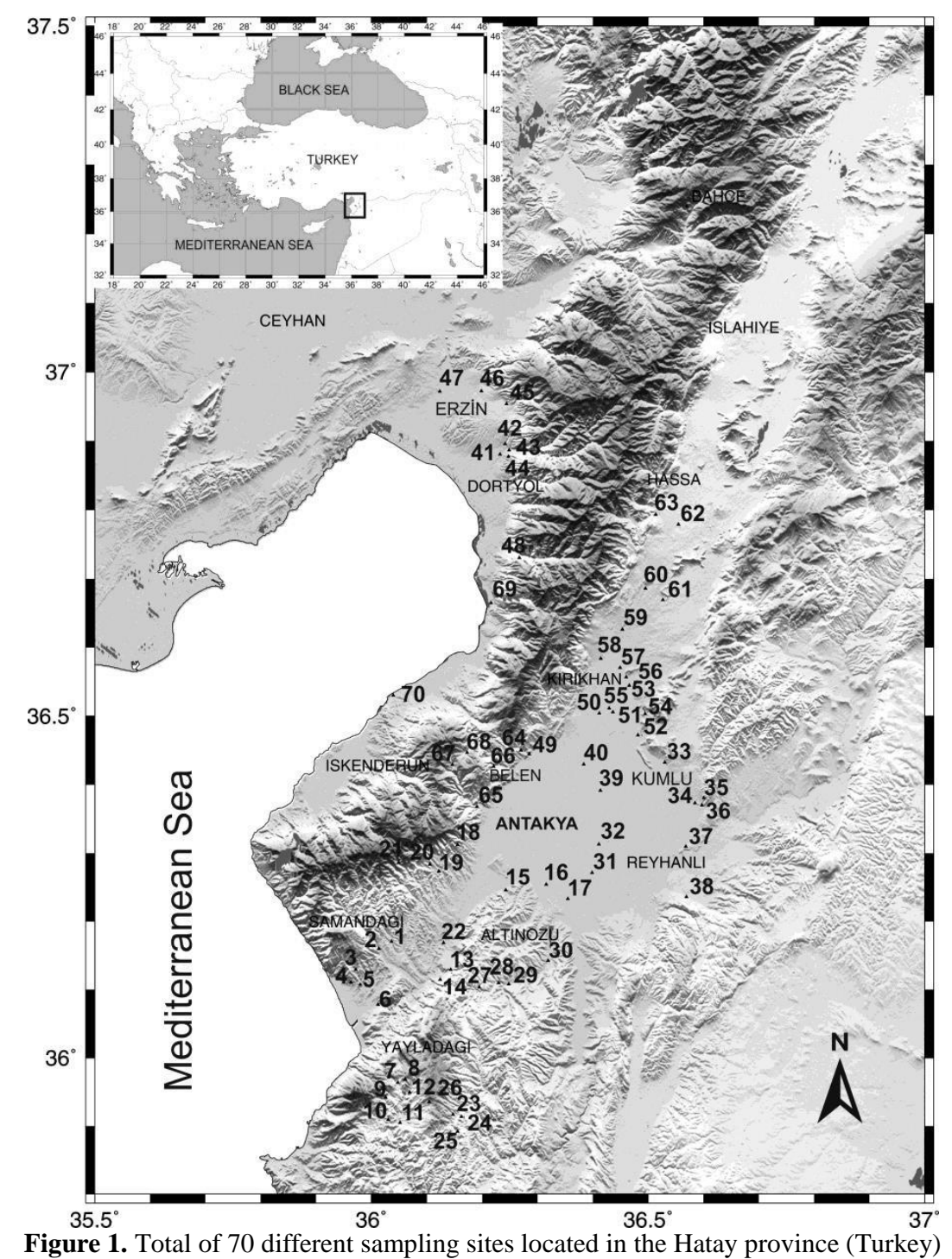

During the sampling, we used a GPS $45 \mathrm{XL}$ for recording the coordinate and elevation of each sampling site. While air temperature $\left(\mathrm{Ta},{ }^{\circ} \mathrm{C}\right)$ and moisture (Moi, \%) were measured by Testo 410-2 model of anemometer, water temperature (Tw, $\left.{ }^{\circ} \mathrm{C}\right), \mathrm{pH}$, dissolved oxygen ( $\left.\mathrm{DO}, \mathrm{mg} \mathrm{L}^{-1}\right)$, saturation $(\mathrm{S}, \%)$, salinity (Sal, ppt), electrical conductivity $\left(\mathrm{EC}, \mu \mathrm{S} \mathrm{cm}^{-1}\right.$ ) and total dissolved solids (TDS, $\mathrm{mg} \mathrm{L}^{1}$ ) were measured by YSI Professional Plus Series in situ. The physicochemical and geographical data of stations along with distributions of the obtaining species were shown in the Appendix.

Shannon-Wiener (H') was calculated via Species Diversity and Richness, version 4 program (Seaby and Henderson 2006) to examine the species diversity within different habitat types. Canonical Correspondence Analysis (CCA) along with Monte Carlo permutation test (499 permutations) was used to determine the most effective environmental variable(s) on species (ter Braak 1986; ter Braak and
Verdonschot 1995). Suitability of CCA was tested with a priori analysis of DCA (Detrended Correspondence Analyses). Length of DCA (>3) suggests possible linear correlation and suitability of the data for CCA. To reduce the influence of multicollinearity and arc-effect, rare species were automatically down-weighted, and the data was log-transformed by the program of Canoco 4. C2 program was used to calculate ecological tolerance and optimum values of individual ostracod species (Juggins 2003). In all statistical analyses, live adults occurred in at least three different samples were used while juveniles, damaged individuals, and sub-fossils were excluded from the analyses. We used Two Way Indicator Species Analysis (TWINSPAN) to estimate the indicator values of individual ostracod species among the habitats in the Community Analysis Package program (CAP 4.1.3) (Seaby and Henderson 2006). This method provides a clustering relationship among the habitats distinguished by species with positive or negative indicator values. 


\section{Results}

Total of 19 ostracod species [Darwinula stevensoni (Brady \& Robertson 1870), Neglecandona neglecta (Sars, 1887), Pseudocandona albicans (Brady, 1864), Cypridopsis vidua (Müller, 1776), Prionocypris zenkeri (Chyzer \& Toth, 1858), Ilyocypris inermis Kaufmann, 1900, I. monstrifica (Norman, 1862), I. bradyi Sars, 1890, Heterocypris salina (Brady, 1868), H. incongruens (Ramdohr, 1808), Herpetocypris intermedia Kaufmann, 1900, H. chevreuxi (Sars, 1896), Psychrodromus olivaceus (Brady \& Norman, 1889), P. fontinalis (Wolf, 1920), Potamocypris fallax Fox, 1967, P. variegata (Brady \& Norman, 1889), Zonocypris costata (Vávra, 1897), Limnocythere cf. stationis Vávra, 1891 and Cyprideis torosa (Jones, 1850)] were found 58 of 70 sites from the study area (Appendix). Additionally, carapaces of two marine ostracods (Pokornyella sp. and Tenedocythere sp.) were obtained from spring water (St. No. 14). Of the species, 14 species (D. stevensoni, N. neglecta, P. albicans, C. vidua, $P$. zenkeri, I. inermis, I. monstrifica, H. intermedia,
P. olivaceus, P. fontinalis, P. fallax, P. variegata, $Z$. costata, $L$. cf. stationis) are new records for this area. Among the species, finding a bisexual population of I. inermis (Sar1 et al. 2012) is important to extend the known geographical distribution of the species toward the southern parts of Turkey.

The distribution of habitat types along with a total number of species and numbers of individuals among the sampling sites at different elevational ranges were shown in Table 1. According to this, both abundance values and numbers of species were found to show a gradual decrease with increasing elevation. Besides, the majority of the stations (21 stations) with the highest habitat diversity (9 types) were found in the range of 101-200 $\mathrm{m}$ a.s.1. The highest species numbers (13 species) were observed at 0-100 $\mathrm{m}$ and $201-300 \mathrm{~m}$, even though the numbers of stations were significantly different with 18 and 11 sites, respectively. On the other hand, the highest number of individuals (abundance) was calculated for 301-400 m with seven sites and 1616 individuals.

Table 1. Distribution of habitat types, the total number of species and individuals according to their grouped elevations with Shannon-Wiener index results for 12 different habitat types

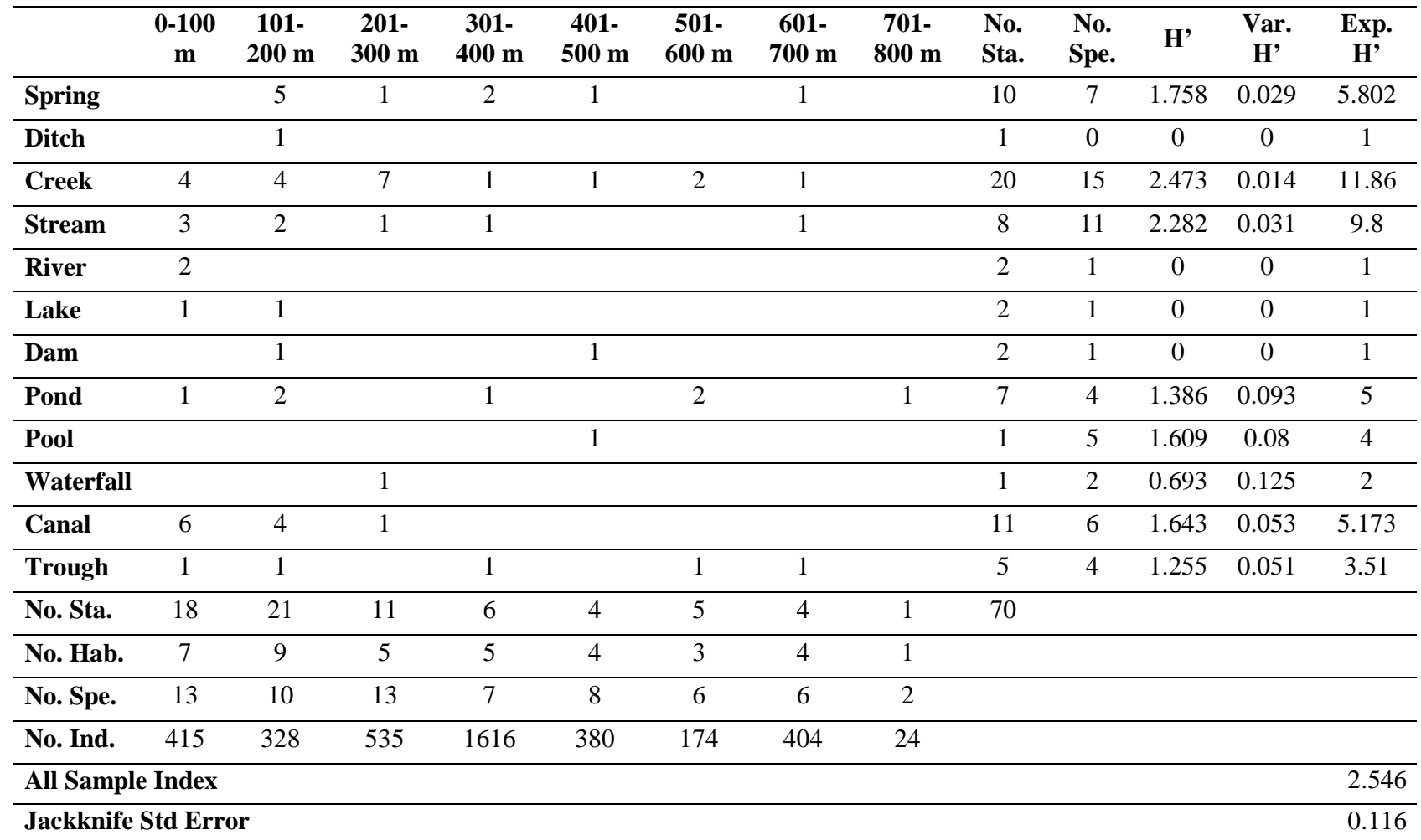

Abbreviations: No. Sta., number of stations; No. Hab., number of habitats; No. Spe.1, number of species; No. Ind., number of individual (abundance) for each of elevational ranges and habitat types; H', Shannon-Wiener Index value; Var. H', variance H'; Exp. H', expected $\mathrm{H}^{\prime}$

Among the habitat types, creeks displayed the highest species diversity $\left(H^{\prime}=2.473\right)$ (Table 1$)$. Following creeks, species diversity was found high in streams $\left(H^{\prime}=2.282\right)$ and spring $\left(H^{\prime}=1.758\right)$ waters.
The first two axes of CCA diagram explained about $79.7 \%$ of the relationship between cumulative percentage variance of species and environmental variables. Eventually, the most influential factors on species were water temperature 
$(P=0.002, F=4.327)$ and electrical conductivity $(P=0.014, F=2.562)$ (Figure $2 \mathrm{a}, \mathrm{b})$.

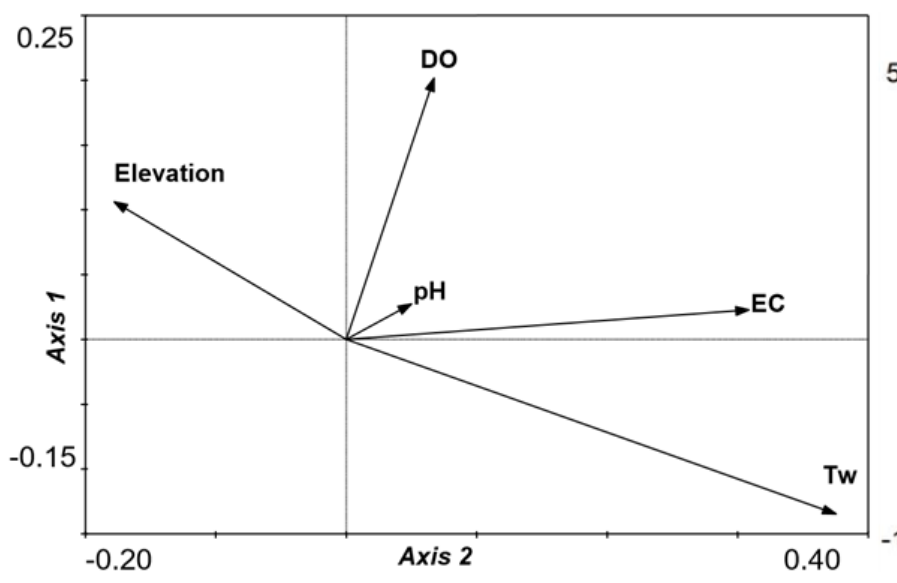

(a)

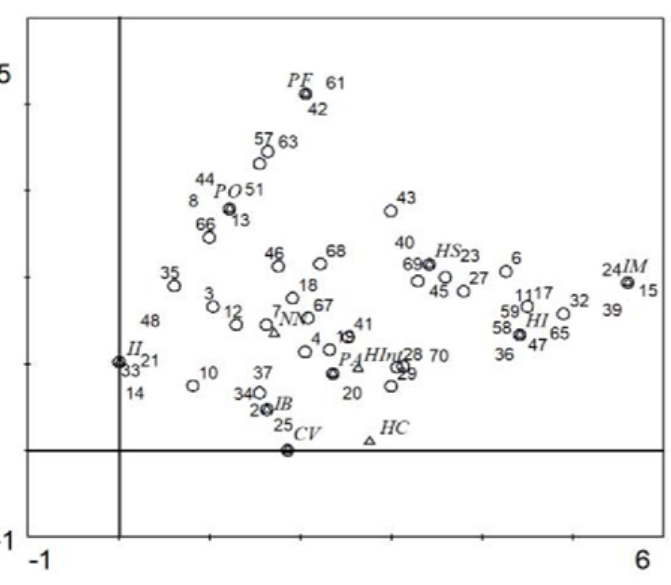

(b)

Figure 2. (a) The most effected environmental variable(s) on species according to CCA, (b) distribution of 12 species, occurred three or more times, with sampling sites

Abbreviations of environmental variables and species are shown in the Appendix.

According to the tolerance and optimum estimate values (Table 2) of the species, two species (H. incongruens and H. salina) displayed the highest tolerance values for dissolved oxygen and salinity (referring to electrical conductivity) while $C$. vidua and $P$. albicans showed the highest values for water temperature and $\mathrm{pH}$, respectively. $H$. chevreuxi known as a pure freshwater species showed the lowest tolerance for water temperature $\left(t_{k}=1.29\right)$ and conductivity $\left(t_{k}=75.85\right)$.

Table 2. Ecological tolerance $\left(t_{k}\right)$ and optimum $\left(u_{k}\right)$ values of 12 species which were occurred three or more times (pH, Tw, DO, EC, Sal.) with maximum, minimum, and average levels for five environmental variables.

\begin{tabular}{lcccccccccccc}
\hline & & & \multicolumn{2}{c}{$\mathbf{p H}$} & \multicolumn{2}{c}{ Tw } & \multicolumn{2}{c}{ DO } & \multicolumn{2}{c}{ EC } & \multicolumn{2}{c}{ Sal. } \\
\hline Code & Count & $\mathbf{N} 2$ & $\boldsymbol{u}_{\boldsymbol{k}}$ & $\boldsymbol{t}_{\boldsymbol{k}}$ & $\boldsymbol{u}_{\boldsymbol{k}}$ & $\boldsymbol{t}_{\boldsymbol{k}}$ & $\boldsymbol{u}_{\boldsymbol{k}}$ & $\boldsymbol{t}_{\boldsymbol{k}}$ & $\boldsymbol{u}_{\boldsymbol{k}}$ & $\boldsymbol{t}_{\boldsymbol{k}}$ & $\boldsymbol{u}_{\boldsymbol{k}}$ & $\boldsymbol{t}_{\boldsymbol{k}}$ \\
\hline HC & 3 & 1.3 & 7.42 & $\mathbf{0 . 3 9}$ & 22.54 & $\mathbf{1 . 2 9}$ & 3.04 & $\mathbf{2 . 6 9}$ & 804.96 & $\mathbf{7 5 . 8 5}$ & 0.41 & $\mathbf{0 . 0 9}$ \\
\hline PA & 3 & 1.32 & 7.67 & $\mathbf{0 . 5 4}$ & 21.93 & $\mathbf{5 . 6 9}$ & 3.54 & $\mathbf{1 . 5 3}$ & 833.38 & $\mathbf{1 7 9 . 8 6}$ & 0.43 & $\mathbf{0 . 1 4}$ \\
\hline HInt & 3 & 1.85 & 8.28 & $\mathbf{0 . 3}$ & 23.78 & $\mathbf{4 . 5 9}$ & 6.08 & $\mathbf{3 . 6 8}$ & 848.62 & $\mathbf{3 8 6 . 3 7}$ & 0.41 & $\mathbf{0 . 2 4}$ \\
\hline PO & 17 & 3.35 & 7.95 & $\mathbf{0 . 4 1}$ & 16.95 & $\mathbf{3 . 3}$ & 7.51 & $\mathbf{2 . 4 8}$ & 452.04 & $\mathbf{2 3 7 . 0 5}$ & 0.25 & $\mathbf{0 . 1 3}$ \\
\hline PF & 4 & 2.64 & 7.86 & $\mathbf{0 . 2 5}$ & 18.83 & $\mathbf{3 . 4 8}$ & 6.76 & $\mathbf{1 . 4}$ & 620.28 & $\mathbf{1 7 3 . 1 9}$ & 0.34 & $\mathbf{0 . 1 1}$ \\
\hline CN & 6 & 1.74 & 7.74 & $\mathbf{0 . 4 9}$ & 20.39 & $\mathbf{2 . 7 4}$ & 4.81 & $\mathbf{3 . 0 6}$ & 719.29 & $\mathbf{1 6 5 . 6 1}$ & 0.38 & $\mathbf{0 . 1 3}$ \\
\hline HI & 12 & 2.91 & 7.99 & $\mathbf{0 . 3 8}$ & 27.37 & $\mathbf{4 . 7}$ & 6.25 & $\mathbf{5 . 8 3}$ & 1512 & $\mathbf{5 3 4 . 3 4}$ & 0.72 & $\mathbf{0 . 2 9}$ \\
\hline HS & 18 & 1.8 & 8.33 & $\mathbf{0 . 4 3}$ & 31.39 & $\mathbf{7 . 6 9}$ & 12.7 & $\mathbf{5 . 7 1}$ & 1624.8 & $\mathbf{5 6 0 . 2 6}$ & 0.7 & $\mathbf{0 . 2 9}$ \\
\hline CV & 4 & 2.15 & 8.22 & $\mathbf{0 . 1 3}$ & 23.56 & $\mathbf{8 . 9 7}$ & 9.3 & $\mathbf{1 . 9 9}$ & 632.66 & $\mathbf{2 9 2 . 9 6}$ & 0.3 & $\mathbf{0 . 1 5}$ \\
\hline IB & 11 & 2.77 & 7.66 & $\mathbf{0 . 3 5}$ & 18.34 & $\mathbf{3 . 1 8}$ & 6.49 & $\mathbf{1 . 2 6}$ & 506.97 & $\mathbf{1 7 2 . 0 2}$ & 0.26 & $\mathbf{0 . 0 8}$ \\
\hline II & 11 & 3.97 & 7.98 & $\mathbf{0 . 3 5}$ & 22.3 & $\mathbf{6 . 5 8}$ & 8.72 & $\mathbf{1 . 7 5}$ & 614.77 & $\mathbf{2 4 0 . 3 1}$ & 0.3 & $\mathbf{0 . 1 1}$ \\
\hline IM & 6 & 2.13 & 7.71 & $\mathbf{0 . 3 1}$ & 25.75 & $\mathbf{1 . 9 5}$ & 6.48 & $\mathbf{2 . 2 5}$ & 1161.1 & $\mathbf{1 3 6 2 . 3}$ & 0.57 & $\mathbf{0 . 8 4}$ \\
\hline & & Mean & 7.9 & $\mathbf{0 . 3 6}$ & 22.76 & $\mathbf{4 . 5 1}$ & 6.81 & $\mathbf{2 . 8}$ & 860.9 & $\mathbf{3 6 5 . 0 1}$ & 0.42 & $\mathbf{0 . 2 2}$ \\
\hline & & Max & 8.33 & $\mathbf{0 . 5 4}$ & 31.39 & $\mathbf{8 . 9 7}$ & 12.7 & $\mathbf{5 . 8 3}$ & 1624.8 & $\mathbf{1 3 6 2 . 3}$ & 0.72 & $\mathbf{0 . 8 4}$ \\
\hline & Min & 7.42 & $\mathbf{0 . 1 3}$ & 16.95 & $\mathbf{1 . 2 9}$ & 3.04 & $\mathbf{1 . 2 6}$ & 452.04 & $\mathbf{7 5 . 8 5}$ & 0.25 & $\mathbf{0 . 0 8}$ \\
\hline & Std Error & 0.28 & $\mathbf{0 . 1 1}$ & 4.063 & $\mathbf{2 . 3 4}$ & 2.61 & $\mathbf{1 . 5 6}$ & 379.54 & $\mathbf{3 4 7 . 8}$ & 0.16 & $\mathbf{0 . 2 1}$ \\
\hline
\end{tabular}

Count and N2 imply numbers of species occurrence and Hill's coefficient (a measure of the effective number of occurrences), respectively. Abbreviations for species and environmental variables were given in the Appendix.

TWINSPAN results outlined that species (e.g., H. chevreuxi) with certain indicator values can be used to discriminate characteristics of habitats (Figure 3). 


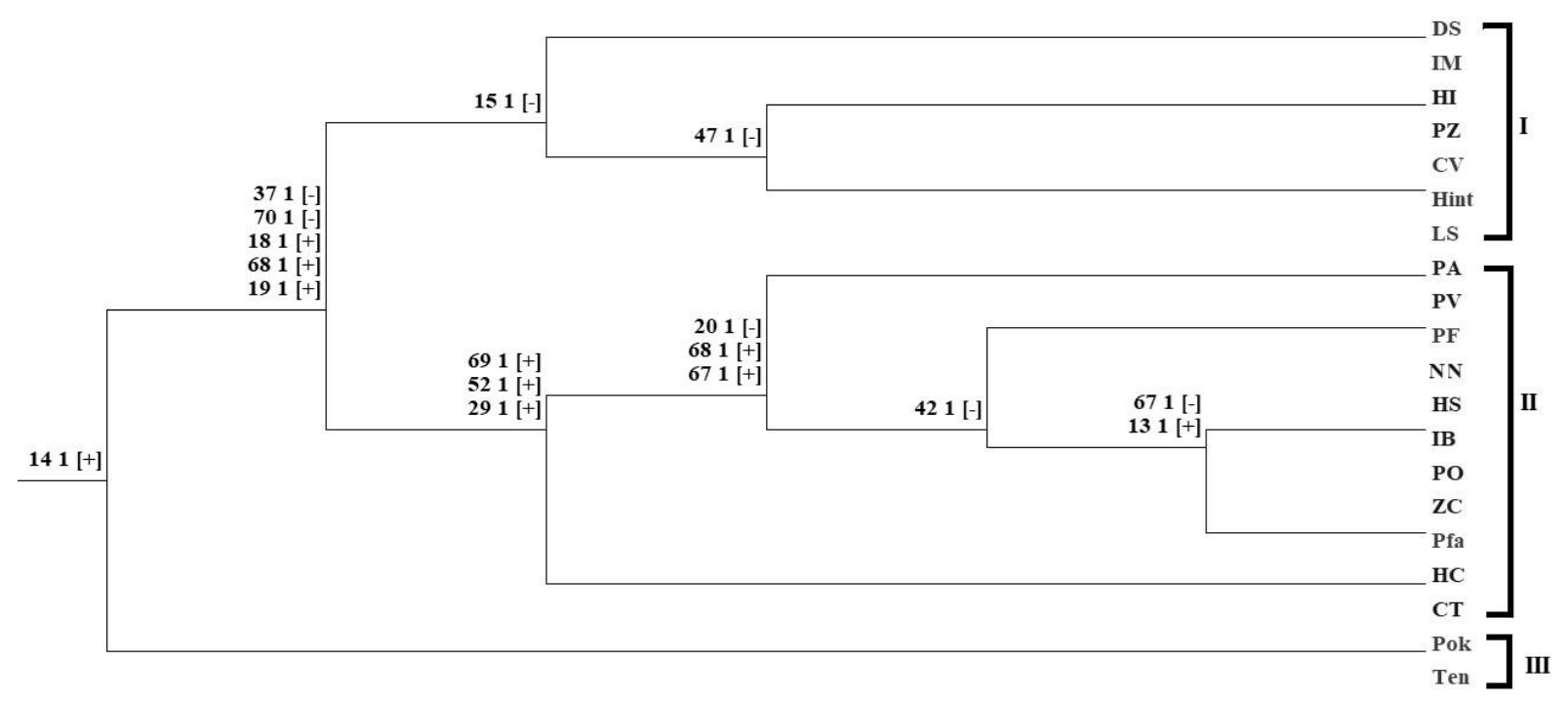

Figure 3. Twinspan dendrogram. Species are clustered into three groups (I-III) while habitats are shown in each node of division. Positive (+) and negative (-) values in parentheses represent the right and left sides of the branch. For abbreviations see Appendix.

\section{Discussion}

Hartmann (1964) was the first to report five ostracod species [Heterocypris incongruens, Heterocypris. salina, Ilyocypris bradyi, Herpetocypris chevreuxi and Potamocypris zschokkei (Kaufmann, 1900)] from the province. Then after, Gülen $(1985,1988)$ found five more species in addition to $H$. salina [Candonopsis kingsleii (Brady \& Robertson, 1870), Eucypris virens (Jurine, 1820), Cypris pubera Müller, 1776, Tonnacypris lutaria (Koch, 1838), Cytherissa lacustris (Sars, 1863)]. Most recently, Özuluğ and K1lıç (2002) listed one more species Costa edwardsii (Roemer, 1838), which is especially known with its preference of marine waters but can also be found in brackish waters (Meisch 2000). Four of these species (H. incongruens, $H$. salina, $I$. bradyi and $H$. chevreuxi) were also found during the present study. Combining the species with our 19 ostracods, total numbers of freshwater ostracods of Hatay province increased to 26 .

Finding 15 of 19 species from the creeks corresponds to highest species richness $\left(H^{\prime}=2.473\right)$ in these habitats. According to Connor and McCoy (1979) more species can be encountered with increasing sampling sites in wider areas. This suggests that there can be a positive correlation between the numbers of species and sampling sites. Thus, the fact that more species were encountered in creeks may be related to the high numbers of sampling efforts (20 out of 70 sites). On the other hand, numbers of samples alone cannot explain relatively high species diversity in different habitat types. For example, streams also had high diversity with 11 species, collected from only 8 different sites
(Table 1). In such a case, we assume that habitat suitability may also play an important role in species diversity and distribution.

In general, the highest number of species was found at low elevations when the least number of species was found at high elevations. According to Rapoport's Rule (see e.g., Stevens 1992), numbers of species decrease with increasing elevation. The results of this study do not correspond to the assumption of the rule due to differences in the numbers of stations and habitat types that the greater part of the stations with more different sampling sites were already situated at low elevations. On the other hand, the situation can be explained with the "habitat diversity hypothesis" (Williams 1943) and then with ecological features that individual species showed. Some species (e.g., $H$. incongruens) with wide tolerance levels to different environmental variables exhibited a wide geographical distribution in a variety of habitats. These species so-called "cosmoecious species" (Külköylüoğlu 2013) usually display elevation free distribution. For example, during the present study, $H$. salina was reported from almost all elevations. In contrast, stenoecious species (e.g., H. chevreuxi) with a narrow tolerance levels to some of those environmental variables are of limited distributional ranges. This may imply that such these species do have advantages over other species. However, cosmoecious species concept does not include biological factors on species distribution that is probably effective with the arrival of species into a new area. As stated above, water temperature plays an important role for water quality and life in aquatic ecosystems (Morril et al. 2005). Besides, herein as illustrated in CCA diagram showed that water temperature was the most effective factor on species 
distribution $(\mathrm{p}<0.05)$. In reality, changes in water temperature are relatively slower and narrower interval ranges than the air temperature due to physicochemical properties of water bodies (Odum and Barrett 2005). This is generally (and especially) true for deep waters. However, in the present study, ostracods were collected from shallow aquatic habitats which are more prone to the influence of changes in air temperature. This supports the idea of Preud'homme and Stefan (1992) that predictions can be better for shallow water bodies than a deeper one. In this way trends of water and air temperatures in each site were changed almost parallel to each other. Following such changes, most of the ostracod species must deal with the new conditions, to which that the species with high tolerances will have better adapted. For instance, when a freshwater habitat is altered to hypersaline waters due to increasing temperature gradients, Cyprideis torosa can survive approximately 30 days in dormant form (Meisch 2000), but stenoecious species can suffer from this change.

In this study, estimating ecological optimum and tolerance values of species revealed that $H$. chevreuxi displayed low tolerance values for water temperature $\left(t_{k}=1.29\right)$ and conductivity $\left(t_{k}=75.85\right)$ (Table 2$)$. This species usually prefers stagnant waters in Turkey but there is not much ecological data about it. In a recent study, $H$. chevreuxi was found among those with low tolerance value for temperature and dissolved oxygen in the shallow waters of Bolu (Turkey) (Külköylüoğlu and Sarı 2012). If the current climatic scenarios are correct, one may consider that $H$. chevreuxi will possibly the first species put under the risk of local extinction in this region due to its low tolerance level for water temperature $\left(t_{k}=1.29\right)$. According to Meisch (2000), the species can be considered as pure freshwater species and its cooccurrence with one or more halophilic ostracods (e.g., Heterocypris salina) indicates an increase in salinity levels of that water body. Our results support this view that $H$. chevreuxi was found from five different sampling sites where the species was commonly found with one or more of those cosmopolitan species (e.g., $H$. salina, $H$. incongruens, I. bradyi, C. vidua) which are known to tolerate different levels of environmental variables, including high levels of salinity changes.

The first two clustering groups in TWINSPAN are separated from group III (Figure 3 ) with five sites where all sites (numbered as 18, 19, 37, 68, 70) were creeks. The species, $H$. chevreuxi, was only found in site 18 where the electrical conductivity value was over the freshwater range (EC $789 \mu \mathrm{S} / \mathrm{cm})$. This may partially reinforce the idea that site 18 can be under the effect of increasing salinity. Six species (except
$H$. incongruens) in group I have rare occurrences in creeks while species in group II have a wide distribution in several different habitat types characterized in freshwater ranges. Supporting evidence can be provided to generalize this result. Considering the dissolved oxygen level, a similar situation is applied to some of the species such as I. bradyi and $P$. fontinalis with low tolerance levels to dissolved oxygen as $t_{k}=1.26$ and $t_{k}=1.4$, respectively. One might reasonably think that since the two species have similar tolerance levels, they are in some sense ecologically equivalent. The same idea may be applied to other species with similar occurrences. Also, C. vidua showed a relatively low tolerance $\left(t_{k}=1.99\right)$ level for oxygen tolerance. Kiss (2007) explained that a low density of $C$. vidua was related to its low tolerance value for poorly oxygenated waters despite its high ecological tolerance levels. Unlike these species, the optimum and tolerance levels of cosmopolitan species such as $N$. neglecta, $H$. incongruens, and $H$. salina were generally higher than the mean values for 12 species (Table 2). Therefore, such species can be considered to tolerate fluctuations in temperature changes and other ecological factors as well.

In conclusion, inland waters, especially the shallow water bodies, are critical for species conservation, biogeochemical cycling, and hydrological management even though they occupy an only a small portion of the Earth (An et al. 2013; Zhang et al. 2020). However, because of current temperature changes elevated by human activities, ecological features of many aquatic habitats have been changed, causing a critical alteration in species composition and their geographic distribution (An et al. 2013; Finlayson et al. 2013). Additionally, it is, however, expected that some ostracod species with low tolerance levels to ecological changes can be affected by such temperature changes earlier than those with high tolerance levels. To make an assumption about which ostracod species can be disappearing in the future (or which will have more chance to survive) is important in terms of the determining of inland waters dynamics due to changes in the structure of biological communities which affect freshwater ecosystem processes negatively (Dudgeon et al. 2006). Nevertheless, longterm studies are required to use ostracods as an early warning sign of changes in shallow-water habitats.

\section{Acknowledgements}

We would like to thank Mr. Avni Hatay and Mr. Mehmet Cemal Tunçay (Hatay Directorate of Provincial Food Agriculture and Livestock), Mr. Murat Zümre (Hatay Mustafa Kemal University), for logistical support during the visit to the study sites 
and Dr. Özlem Makaroğlu (İstanbul UniversityCerrahpaşa) for drawing topographic map of Hatay. Part of this study was presented within an oral presentation at the 17th International Symposium on Ostracoda in Rome, Italy.

\section{References}

An S, Tian Z, Cai Y, Wen T, Xu D, Jiang H, Yao Z, Guan B, Sheng S, Ouyang Y, Cheng, X. 2013. Wetlands of Northeast Asia and high Asia: an overview. Aquat Sci. 75(1):63-71. doi: 10.1007/s00027-012-0281-4

Benateau S, Gaudard A, Stamm C, Altermatt F. 2019. Climate change and freshwater ecosystems: Impacts on water quality and ecological status. Bern, Switzerland: Federal Office for the Environment (FOEN). Project No.: Hydro$\mathrm{CH} 2018$.

Black SH, Shepard M, Allen MM. 2001. Endangered Invertebrates: the case for greater attention to invertebrate conservation. Endangered Species Update. 18(2):41-49.

Broodbakker NW, Danielopol DL. 1982. The chaetotaxy of Cypridacea (Crustacea, Ostrocoda) limbs: proposals for a descriptive model. Bijdr Dierkd. 52(2):103-120. doi: 10.1163/26660644-05202003

Connor EF, McCoy ED. 1979. The statistics and biology of the species-area relationship. Am Nat. 113(6): 791-833.

Demircan M, Gürkan H, Eskioğlu O, Arabacı H, Coşkun M. 2017. Climate change projections for Turkey: three models and two scenarios. Tr J Water Sci \& Manag. 1(1):22-43.

Dudgeon D, Arthington AH, Gessner MO, Kawabata ZI, Knowler DJ, Lévêque C, Naiman RJ, Prieur-Richard AH, Soto D, Staissny MLJ, Sullivan CA. 2006. Freshwater biodiversity: importance, threats, status and conservation challenges. Biol Rev. 81(2): 163-182. doi: 10.1017/S1464793105006950

Eisenhauer N, Bonn A, Guerra CA. 2019. Recognizing the quiet extinction of invertebrates. Nat. Commun. $10: 1-3$.

Ertürk A. 2012. Managing the effects of the climate change on water resources and watershed ecology. In: Kumarasamy $\mathrm{M}$, editor. Studies on water management issues, Chapter 11. Rijeka, Croatia: Intech Open Access Publisher. p. 259-274.

Finlayson CM, Davis A, Gell PA, Kingsford RT, Parton KA. 2013. The status of wetlands and the predicted effects of global climate change: the situation in Australia. Aquat Sci. 75(1):73-93. doi: 10.1007/s00027-011-0232-5

Gülen D. 1985. The species and distribution of the group Podocopa (Ostracoda-Crustacea) in the fresh waters of western Anatolia. İstanbul Üniv Fen Fak Mecm. Seri B. 50: $65-80$.

Gülen D. 1988. Türkiye tatlısu ostracod faunasına katkılar II. İstanbul Üniv Su Ürün Derg. 2:199-202.
Hartmann G. 1964. Asiatische ostracoden: systematische und zoogeographische untersuchungen. Berlin: Akademie Verlag GmbH 155 p.

IPCC 2007: Climate Change 2007: Impacts, Adaptation and Vulnerability. Contribution of Working Group II to the Fourth Assessment Report of the Intergovernmental Panel on Climate Change, M.L. Parry, O.F. Canziani, J.P. Palutikof, P.J. van der Linden and C.E. Hanson, Eds. Cambridge, UK: Cambridge University Press, 976 p.

Jourdan J, O'Harab RB, Bottarin R, Huttunen KL, Kuemmerlen M, Monteith D, Muotko T, Ozolins D, Paavola R, Pilotto F, Springe G, Skuja A, Sundermann A, Tonkin JD, Haase P. 2018. Effects of changing climate on European stream invertebrate communities: A long-term data analysis. Sci Total Environ. 621:588-599.

doi: 10.1016/j.scitotenv.2017.11.242

Juggins S. 2003. Software for Ecological and Palaeoecological Data Analysis and Visualization, C2 User Guide. Newcastle-Upon-Tyne: University of Newcastle $77 \mathrm{p}$.

Karabulut M. 2009. Precipitation Trends in Kahramanmaraş along with Gaziantep and Adiyaman during the period of 1963-2005. Ekoloji. 18:15-24.

Karanovic I. 2006. Recent Candoninae (Crustacea, Ostracoda) of North America. Rec West Aust Mus. 71:1-75.

Karanovic I. 2012. Recent freshwater ostracods of the world: Crustacea, Ostracoda, Podocopida. Heidelberg, Berlin: Springer Science \& Business Media 608 p.

Kempf EK. 1980. Index and Bibliography of Nonmarine Ostracoda. Parts 1-4. Sonderveröff. geol. Inst. Köln 35 (Index A): 1-188; 36 (Index B): 1-180; 37 (Index C): 1-204; 38 (Bibliography A): 1-186.

Kempf EK. 1997. Index and Bibliography of Nonmarine Ostracoda. Parts 6 and 7. Sonderveröff. geol. Inst. Köln 109 (Part 6: Index A Supplement 1): 1-142; 110 (Part 7: Index B Supplement 1): 1-134; 111 (Part 8: Index C Supplement 1): 1-152; 112 (Part 9: Bibliography C): 1-144.

Kiss A. 2007. Factors affecting spatial and temporal distribution of Ostracoda assemblages in different macrophyte habitats of a shallow lake (Lake Fehér, Hungary). Hydrobiologia. 585:89-98. doi: 10.1007/s10750-007-0631-8

Külköylüoğlu O. 2013. Diversity, distribution, and ecology of nonmarine Ostracoda (Crustacea) in Turkey: application of pseudorichness and cosmoecious species concepts. Recent Res Devel Ecol. 4:1-18.

Külköylüoğlu O, Sarı N. 2012. Ecological characteristics of the freshwater Ostracoda in Bolu Region (Turkey). Hydrobiologia. 688:37-46.

Leigh C. 2013. Dry-season changes in macroinvertebrate assemblages of highly seasonal rivers: responses to low flow, no flow and antecedent hydrology. Hydrobiologia. 703(1):95-112. doi: 10.1007/s10750-012-1347-y

Meisch C. 1984. Revision of the recent Western Europe species of genus Potamocypris (Crustacea, Ostracoda). Part I. Species with short 
swimming setae on the second antennae. Mus Hist Nat Lux. 3(3):1-55.

Meisch C. 1985. Revision of the recent west European species of the genus Potamocypris (Crustacea, Ostracoda) Part II. Species with long swimming setae on the second antennae. Mus Hist Nat Lux. 4(3):1-95.

Meisch C. 2000. Freshwater Ostracoda of Western and Central Europe. Süßwasserfauna von Mitteleuropa 8/3. Heidelberg, Berlin: Spektrum Akademischer Verlag $522 \mathrm{p}$.

Meisch K, Smith RJ, Martens K. 2019. A subjective global checklist of the extant non-marine Ostracoda (Crustacea). Eur J Taxon. 492:1-135. doi: 10.5852/ejt.2019.492

Mesquita-Joanes, F, Smith, AJ, Viehberg, FA. 2012. The ecology of Ostracoda across levels of biological organisation from individual to ecosystem: a review of recent developments and future potential. Dev Quat Sci. 17:15-35.

doi: 10.1016/B978-0-444-53636-5.00002-0

Morrill JC, Bales RC, Conklin MH. 2005. Estimating stream temperature from air temperature: implications for future water quality. J Environ Eng. 131:139-146. doi: 10.1061/(ASCE)0733-9372(2005)131:1(139)

Odum EP, Barrett GW. 2005. Fundamentals of Ecology. Thomson Learning Brooks/Cole, Belmont, CA, USA, 624 p. [Turkish translation: Ekoloji'nin Temel İlkeleri, 2008, Işık K (ed). Palme, 5th ed. Ankara].

Özuluğ O, Kılıç M. 2002. Anadolu Ostracoda (Crustacea) faunasına katkılar. İstanbul Üniv $\mathrm{Su}$ Ürün Derg. 14:71-79. [in Turkish]

Preud'homme EB, Stefan HG. 1992. Relationship between water temperatures and air temperatures for Central U.S. streams. Duluth: Environmental Research Laboratory U.S., Environmental Protection
Agency. Project Report No.: 333.

Ragab R, Prudhomme C. 2002. Climate change and water resources management in arid and semi-arid regions: prospective and challenges for the $21^{\text {st }}$ century. Biosyst Eng. 81(1):3-34. doi: 10.1006/bioe.2001.0013

Ruiz F, Abad M, Bodergat AM, Carbonel P, RodríguezLázaro J, González-Regalado ML, Toscano A, Garcia EX, Prenda J. 2013. Freshwater ostracods as environmental tracers. Int $\mathrm{J}$ Environ Sci Te. 10(5):1115-1128.

Sarı N, Külköylüoğlu O, Akdemir D. 2012. First record and detailed description of the male of Ilyocypris inermis Kaufmann, 1900 (Crustacea, Ostracoda). Turk J Zool. 36(4):484-495. doi: 10.3906/zoo-1012-78

Seaby RM, Henderson PA. 2006. Species diversity and richness, Version 4. Lymington, UK: Pisces Conservation Ltd. $132 \mathrm{p}$.

Stevens GC. 1992. The elevational gradient in altitudinal range: an extension of Rapoport's latitudinal rule to altitude. Am Nat. 140(6):893-911. doi: $10.1086 / 285447$

ter Braak CJ. 1986. Canonical correspondence analysis: a new eigenvector technique for multivariate direct gradient analysis. Ecology. 67(5):1167-1179.

ter Braak CJ, Verdonschot PF. 1995. Canonical correspondence analysis and related multivariate methods in aquatic ecology. Aquat Sci. 57(3): 255-289. doi: $10.1007 / \mathrm{bf0} 0877430$

Williams CB. 1943. Area and number of species. Nature. 152:264-267.

Zhang C, Wen L, Wang Y, Liu C, Zhou Y, Lei G. 2020. Can constructed wetlands be wildlife refuges? A review of their potential biodiversity conservation value. Sustainability. 12(4):144 


\section{Appendix.}

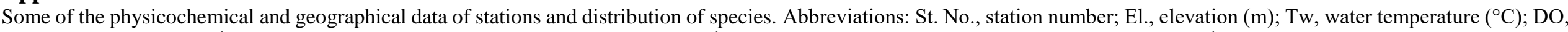

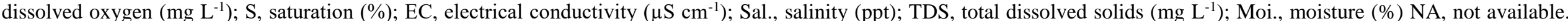

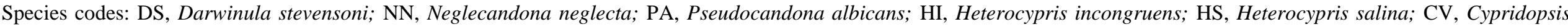

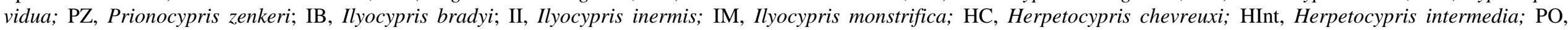

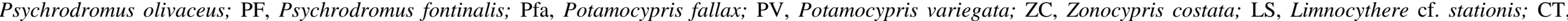
Cyprideis torosa; Pok.sp., Pokornyella sp.; Ten.sp., Tenedocythere sp. Note that species with italic represent sub-fossil (carapace or valves) forms.

\begin{tabular}{|c|c|c|c|c|c|c|c|c|c|c|c|c|c|c|}
\hline St. No & St. Name & Latitude N & Longitude E & El. & $\mathbf{T w}$ & $\mathbf{P h}$ & DO & $\mathbf{S}$ & EC & Sal. & TDS & $\mathbf{T a}$ & Moi. & Species codes \\
\hline 1 & Karamanlı Pond & $36^{\circ} \quad 10.109^{\prime}$ & $036^{\circ} 01.888^{\prime}$ & NA & 29.5 & 8.49 & 6.01 & 76.7 & 592.0 & 0.26 & 0.351 & 30.8 & 56.5 & IB \\
\hline 2 & Batı Ayaz Creek & $36^{0} \quad 09.606^{\prime}$ & $036^{\circ} 00.799^{\prime}$ & NA & 28.4 & 8.69 & 7.32 & 98.3 & 496.9 & 0.22 & 0.300 & 34.7 & 63.3 & NN, IB, II, PO \\
\hline 3 & Hıdır Bey Creek & $36^{\circ} 07.767^{\prime}$ & $035^{\circ} 58.311^{\prime}$ & 162 & 15.7 & 7.61 & 8.07 & 83.3 & 297.1 & 0.20 & 0.234 & 32.4 & 63.7 & $\mathrm{HS}, \mathrm{IB}, \mathrm{PO}$ \\
\hline 4 & Irrigation Canal & $36^{\circ} 06.910^{\prime}$ & $035^{\circ} 58.496^{\prime}$ & 159 & 19.3 & 7.77 & 6.15 & 66.7 & 326.2 & 0.18 & 0.238 & 30.8 & 70.3 & \\
\hline 5 & Small Ditch Water & $36^{\circ} 06.598^{\prime}$ & $035^{\circ} 58.610^{\prime}$ & 117 & 16.6 & 7.70 & 9.42 & 97.3 & 295.8 & 0.17 & 0.228 & 31.8 & 74.5 & HS, IM, $C T$ \\
\hline 6 & Asi River & $36^{\circ} 04.710^{\prime}$ & $036^{\circ} 00.742^{\prime}$ & 11 & 30.3 & 8.60 & 13.6 & 190.6 & 1076 & 0.48 & 0.637 & 36.9 & 57.2 & $\mathrm{HS}, \mathrm{IB}, \mathrm{PO}, C T$ \\
\hline 7 & Leylekli Creek & $35^{\circ} 57.818^{\prime}$ & $036^{\circ} 02.863^{\prime}$ & 522 & 17.1 & 7.44 & 6.1 & 63.7 & 635 & 0.31 & 0.409 & 28.0 & 65.6 & $\mathrm{PO}$ \\
\hline 8 & Through & $35^{\circ} 57.237^{\prime}$ & $036^{\circ} 03.562^{\prime}$ & 551 & 16.7 & 7.33 & 7.81 & 77.5 & 415.3 & 0.24 & 0.320 & 31.5 & 65.6 & LS \\
\hline 9 & Leylekli Dam Lake & $35^{\circ} 56.730^{\prime}$ & $036^{\circ} 03.536^{\prime}$ & 490 & 29.4 & 8.55 & 5.24 & 68.9 & 439.7 & 0.19 & 0.262 & 34.4 & 57.8 & IB, II, PV \\
\hline 10 & Devrent Creek & $35^{\circ} 54.547^{\prime}$ & $036^{\circ} 01.833^{\prime}$ & 426 & 20.0 & 7.28 & 2.71 & 32.1 & 630 & 0.34 & 0.448 & 30.4 & 61.4 & $\mathrm{HI}$ \\
\hline 11 & Kureyşi Creek & $35^{\circ} 54.268^{\prime}$ & $036^{\circ} 03.108^{\prime}$ & 389 & 29.1 & 7.92 & 1.67 & 22.0 & 697 & 0.31 & 0.402 & 30.0 & 66.7 & NN, CV, IB, II, PO \\
\hline 12 & Yayla Kastalı Through & $35^{\circ} 56.730^{\prime}$ & $036^{\circ} 03.536^{\prime}$ & 490 & 14.9 & 8.19 & 8.96 & 89.0 & 291.9 & 0.17 & 0.235 & 29.3 & 65.1 & $\mathrm{PO}, \mathrm{PFa}$ \\
\hline 13 & Harbiye Waterfall & $36^{\circ} 07.755^{\prime}$ & $036^{\circ} 08.613^{\prime}$ & 252 & 17.3 & 8.31 & 9.20 & 95.3 & 413 & 0.23 & 0.314 & 29.9 & 69.4 & II \\
\hline 14 & Spring Water & $36^{\circ} 06.901^{\prime}$ & $036^{\circ} 07.466^{\prime}$ & 282 & 16.6 & 7.59 & 9.13 & 93.3 & 396 & 0.23 & 0.306 & 29.9 & 70.8 & IM, Pok.sp., Ten.sp. \\
\hline 15 & Narlica Creek & $36^{\circ} 14.756^{\prime}$ & $036^{\circ} 14.581^{\prime}$ & 149 & 25.3 & 7.60 & 7.10 & 86.4 & 684 & 0.33 & 0.442 & 31.5 & 65.3 & DS \\
\hline 16 & Irrigation Canal & $36^{\circ} 15.250^{\prime}$ & $036^{\circ} 18.965^{\prime}$ & 115 & 30.8 & 7.67 & 1.77 & 2316 & 1217 & 0.54 & 0.708 & 33.0 & 58.2 & HI, HS, IM \\
\hline 17 & Through & $36^{\circ} 13.981^{\prime}$ & $036^{\circ} 21.320^{\prime}$ & 91 & 25.4 & 7.74 & 4.67 & 58.0 & 1747 & 0.88 & 1.131 & 31.8 & 61.2 & NN, PA, HS, PO \\
\hline 18 & Oğlakören Creek & $36^{\circ} 16.970^{\prime}$ & $036^{\circ} 08.086^{\prime}$ & 242 & 20.8 & 7.57 & 3.66 & 41.5 & 789 & 0.42 & 0.559 & 33.3 & 60.5 & $\mathrm{HS}, \mathrm{IB}, \mathrm{HC}, \mathrm{PO}$ \\
\hline 19 & Küçük Creek & $36^{\circ} 16.748^{\prime}$ & $036^{\circ} 07.188^{\prime}$ & 267 & 24.0 & 7.94 & 6.52 & 79.1 & 606 & 0.29 & 0.396 & 32.3 & 61.1 & $\mathrm{PA}, P Z, H C$ \\
\hline
\end{tabular}


(Appendix continued)

\begin{tabular}{|c|c|c|c|c|c|c|c|c|c|c|c|c|c|c|}
\hline St. No & St. Name & Latitude N & Longitude E & El. & $\mathbf{T w}$ & $\mathbf{P h}$ & DO & $\mathbf{S}$ & EC & Sal. & TDS & Ta & Moi. & Species codes \\
\hline 20 & Karlısu Central Irrigation Pond & $\begin{array}{ll}36^{\circ} & 17.026^{\prime}\end{array}$ & $036^{\circ} 06.366^{\prime}$ & 358 & 30.0 & 8.70 & 5.67 & 75.3 & 580 & 0.26 & 0.344 & 32.0 & 49.2 & II \\
\hline 21 & Kisecik Creek & $36^{\circ} 17.152^{\prime}$ & $036^{\circ} 02.940^{\prime}$ & 658 & 23.4 & 8.43 & 6.20 & 73.5 & 574 & 0.29 & 0.383 & 35.5 & 49.7 & \\
\hline 22 & Asi River & $36^{\circ} 10.117^{\prime}$ & $036^{\circ} 07.827^{\prime}$ & 59 & 28.9 & 8.14 & 7.33 & 93.4 & 1221 & 0.56 & 0.741 & 33.3 & 53 & HS \\
\hline 23 & Görentaş Through & $35^{\circ} 55.036^{\prime}$ & $036^{\circ} 08.859^{\prime}$ & 605 & 23.6 & 7.95 & 6.85 & 83.0 & 679 & 0.34 & 0.455 & 33.4 & 38.1 & $\mathrm{IM}$ \\
\hline 24 & Görentaş Pond & $35^{\circ} 54.807^{\prime}$ & $036^{\circ} 09.743^{\prime}$ & 524 & 28.3 & 8.55 & 8.25 & 99.4 & 401.8 & 0.18 & 0.245 & 37.3 & 33.3 & $\mathrm{CV}, I B$ \\
\hline 25 & Güveçci Pond & $35^{\circ} 53.508^{\prime}$ & $036^{\circ} 09.337^{\prime}$ & 529 & 30.7 & 8.76 & 8.73 & 117.7 & 555 & 0.24 & 0.325 & 35.3 & 50.0 & $H I, I B$ \\
\hline 26 & Yalaz Pond & $35^{\circ} 56.135^{\prime}$ & $036^{\circ} 06.287^{\prime}$ & 740 & 28.3 & 8.38 & 6.23 & 80.1 & 361.1 & 0.16 & 0.221 & 37.0 & 26.4 & HI, HS \\
\hline 27 & Kozkalesi Through & $36^{\circ} 06.221^{\prime}$ & $036^{\circ} 11.700^{\prime}$ & 374 & 34.5 & 8.49 & 15.03 & 217 & 1941 & 0.81 & 1.066 & 35.1 & 26.5 & $\mathrm{HS}, \mathrm{HC}$ \\
\hline 28 & Kuseyri Creek & $36^{\circ} 06.607^{\prime}$ & $036^{\circ} 13.785^{\prime}$ & 252 & 22.3 & 7.35 & 2.53 & 29.5 & 831 & 0.43 & 0.572 & 33.6 & 41.9 & $\mathrm{HS}, \mathrm{HC}$ \\
\hline 29 & Tokaçlı Creek & $36^{\circ} 06.507^{\prime}$ & $036^{\circ} 14.913^{\prime}$ & 231 & 24.8 & 7.69 & 5.23 & 67.0 & 818 & 0.40 & 0.533 & 34.0 & 51.9 & $C T$ \\
\hline 30 & Yarseli Dam Lake & $36^{\circ} 08.554^{\prime}$ & $036^{\circ} 19.148^{\prime}$ & 177 & 29.6 & 8.08 & 6.86 & 91.2 & 855 & 0.38 & 0.513 & 35.0 & 49.5 & \\
\hline 31 & Irrigation Canal & $36^{\circ} 16.271^{\prime}$ & $036^{\circ} 23.918^{\prime}$ & 93 & 28.4 & 7.78 & 3.72 & 48.1 & 1209 & 0.66 & 0.741 & 34.3 & 50 & HI, IM \\
\hline 32 & Afrin Irrigation Canal & $36^{\circ} 18.764^{\prime}$ & $036^{\circ} 24.655^{\prime}$ & 109 & 27.2 & 8.19 & 3.41 & 44.5 & 963 & 0.45 & 0.598 & 34.6 & 46.9 & II \\
\hline 33 & Akpınar Creek & $36^{\circ} 25.939^{\prime}$ & $036^{\circ} 31.810^{\prime}$ & 92 & 22.2 & 7.68 & 6.71 & 72.2 & 682 & 0.35 & 0.468 & 31.8 & 52.5 & IB \\
\hline 34 & Spring Water & $36^{\circ} 22.664^{\prime}$ & $036^{\circ} 35.671^{\prime}$ & 114 & 29.5 & 7.56 & 4.29 & 56.4 & 804 & 0.36 & 0.481 & NA & 51.6 & II, PO \\
\hline 35 & Spring Water & $36^{\circ} 22.574^{\prime}$ & $036^{\circ} 35.675^{\prime}$ & 114 & 24.4 & 7.22 & 2.89 & 34.6 & 727 & 0.36 & 0.474 & 37.3 & 51.6 & $\mathrm{HI}$ \\
\hline 36 & Spring Water & $36^{\circ} 22.433^{\prime}$ & $036^{\circ} 35.753^{\prime}$ & 111 & 34.8 & 6.84 & 1.44 & 21.9 & 2743 & 1.40 & 1.781 & 40.3 & 49.2 & HI, CV, IB, II, LS \\
\hline 37 & Afrin Stream & $36^{\circ} 18.259^{\prime}$ & $036^{\circ} 32.796^{\prime}$ & 85 & 28.4 & 8.22 & 9.96 & 128 & 815 & 0.37 & 0.494 & 41.3 & 33.6 & \\
\hline 38 & Yenişehir Lake & $36^{\circ} 14.173^{\prime}$ & $036^{\circ} 34.165^{\prime}$ & 177 & 29.8 & 8.11 & 6.92 & 94.4 & 622 & 0.27 & 0.370 & 35.2 & 39.8 & $\mathrm{IM}, P Z$ \\
\hline 39 & Murat Paşa Irrigation Canal & $36^{\circ} 23.497^{\prime}$ & $036^{\circ} 24.828^{\prime}$ & 98 & 33.1 & 8.01 & 7.40 & 107.8 & 9205 & 4.36 & 5.187 & 37.5 & 40.5 & HS \\
\hline 40 & Comba Irrigation Canal & $36^{\circ} 25.794^{\prime}$ & $036^{\circ} 23.026^{\prime}$ & 76 & 32.1 & 8.16 & 4.39 & 59.7 & 1418 & 0.64 & 0.851 & 35.3 & 37.7 & $\mathrm{CT}, \mathrm{HS}, \mathrm{IB}$ \\
\hline 41 & Deli Stream & $36^{\circ} 52.846^{\prime}$ & $036^{\circ} 13.957^{\prime}$ & 98 & 19.6 & 8.41 & 8.77 & 97.2 & 520 & 0.28 & 0.377 & 32.2 & 59.4 & \\
\hline 42 & Spring Water & $36^{\circ} 53.218^{\prime}$ & $036^{\circ} 14.947^{\prime}$ & 132 & NA & NA & NA & NA & NA & NA & NA & 31.3 & 59.6 & $\mathrm{HS}, \mathrm{PF}$ \\
\hline
\end{tabular}


(Appendix continued)

\begin{tabular}{|c|c|c|c|c|c|c|c|c|c|c|c|c|c|c|}
\hline St. No & St. Name & Latitude N & Longitude E & El. & $\mathbf{T w}$ & $\mathbf{P h}$ & DO & $\mathbf{S}$ & EC & Sal. & TDS & Ta & Moi. & Species codes \\
\hline 43 & Spring Water & $36^{\circ} 53.218^{\prime}$ & $036^{\circ} 14.947^{\prime}$ & NA & 19.9 & 7.91 & 77.8 & 7.22 & 797 & 0.44 & 0.572 & NA & NA & $\mathrm{PO}$ \\
\hline 44 & Sulu Creek & $36^{\circ} 52.654^{\prime}$ & $036^{\circ} 14.841^{\prime}$ & 207 & 22.5 & 8.48 & 7.71 & 89 & 561 & 0.29 & NA & 32.2 & 56.9 & HS, HI, IB \\
\hline 45 & Irrigation Canal & $36^{\circ} 57.232^{\prime}$ & $036^{\circ} 14.669^{\prime}$ & 295 & 23.3 & 8.47 & 9.07 & 108.6 & 1133 & 0.58 & 0.767 & 37.1 & 46.3 & NN, HS, II, PO \\
\hline 46 & Acısu Spring Water & $36^{\circ} 57.564^{\prime}$ & $036^{\circ} 15.878^{\prime}$ & 391 & 19.4 & 7.85 & 104.7 & 9.36 & 1115 & 0.62 & 0.812 & 32.0 & 61.2 & HI, PZ, II \\
\hline 47 & İssos Creek & $36^{\circ} 58.325^{\prime}$ & $036^{\circ} 07.425^{\prime}$ & 62 & 32.2 & 8.44 & 5.11 & 71.3 & 674 & 0.25 & 0.383 & 37.9 & 61.2 & II \\
\hline 48 & Virgin Mary Spring Water & $36^{\circ} 43.852^{\prime}$ & $036^{\circ} 16.043^{\prime}$ & 601 & 16.0 & 8.14 & 9.42 & 95.8 & 501 & 0.30 & 0.396 & 30.4 & 71.2 & \\
\hline 49 & Creek & $36^{\circ} 26.668^{\prime}$ & $036^{\circ} 17.119^{\prime}$ & 298 & 26.3 & 8.46 & 7.98 & 99.3 & 419.6 & NA & 0.266 & 35.9 & 50.1 & \\
\hline 50 & Karasu Stream & $36^{\circ} 30.265^{\prime}$ & $036^{\circ} 24.717^{\prime}$ & 181 & 25.2 & 8.11 & 6.16 & 73.6 & 796 & 0.39 & 0.513 & 34.4 & 45.1 & $\mathrm{PO}$ \\
\hline 51 & Irrigation Canal & $36^{\circ} 30.361^{\prime}$ & $036^{\circ} 26.209^{\prime}$ & 131 & 27.6 & 8.04 & 4.06 & 55.3 & 670 & 0.31 & 0.416 & 36.5 & 40.4 & \\
\hline 52 & Irrigation Canal & $36^{\circ} 28.350^{\prime}$ & $036^{\circ} 28.881^{\prime}$ & 91 & 29.4 & 7.74 & 2.28 & 30.9 & 769 & 0.34 & 0.461 & 38.1 & 48.4 & $\mathrm{CT}$ \\
\hline 53 & Irrigation Canal & $36^{\circ} 32.698^{\prime}$ & $036^{\circ} 27.946^{\prime}$ & 88 & 25.8 & 8.16 & 5.68 & 70.7 & 617 & 0.29 & 0.396 & 41.2 & 44.4 & \\
\hline 54 & Gülbaşı Lake & $36^{\circ} 30.193^{\prime}$ & $036^{\circ} 29.667^{\prime}$ & 89 & 30.0 & 7.85 & 123.3 & 9.19 & 787 & 0.35 & 0.469 & 40.2 & 27.8 & \\
\hline 55 & Irrigation Canal & $36^{\circ} 30.713^{\prime}$ & $036^{\circ} 25.767^{\prime}$ & 92 & 30.4 & 8.24 & 6.53 & 88.9 & 635 & 0.28 & 0.377 & 40.1 & 50.1 & II \\
\hline 56 & Creek & $36^{\circ} 33.420^{\prime}$ & $036^{\circ} 27.629^{\prime}$ & 87 & 26.9 & 8.07 & 5.93 & 74.7 & 614 & 0.29 & 0.383 & 38.8 & 44.1 & $\mathrm{PO}, \mathrm{PF}$ \\
\hline 57 & Çamsarı Pond & $36^{\circ} 34.236^{\prime}$ & $036^{\circ} 26.957^{\prime}$ & 94 & 26.5 & 8.22 & 6.86 & 73.5 & 649 & 0.30 & 0.409 & 42.3 & 38.8 & $\mathrm{HI}$ \\
\hline 58 & Güzelce Through & $36^{\circ} 35.023^{\prime}$ & $036^{\circ} 24.879^{\prime}$ & 107 & 24.9 & 8.14 & 151 & 12.42 & 594 & 0.29 & 0.390 & 41.9 & 38.8 & $\mathrm{HI}$ \\
\hline 59 & Irrigation Canal & $36^{\circ} 37.586^{\prime}$ & $036^{\circ} 27.233^{\prime}$ & 142 & 19.8 & 7.90 & 8.98 & 98.9 & 598 & 0.32 & 0.435 & 37.6 & 38.4 & \\
\hline 60 & Karapınar Creek & $36^{\circ} 41.147^{\prime}$ & $036^{\circ} 29.728^{\prime}$ & 216 & 26.8 & 8.13 & 109.1 & 8.79 & 450.6 & 0.21 & 0.292 & 38.9 & 36.9 & $\mathrm{PF}$ \\
\hline 61 & Stream & $36^{\circ} 40.173^{\prime}$ & $036^{\circ} 31.623^{\prime}$ & 202 & 19.9 & 8.29 & 8.04 & 89.6 & 345.3 & 0.18 & 0.248 & 47.9 & 24.8 & DS \\
\hline 62 & Höpüren Stream & $36^{\circ} 46.743^{\prime}$ & $036^{\circ} 33.292^{\prime}$ & 336 & 26.0 & 8.21 & 8.28 & 104.6 & 663 & 0.31 & 0.422 & 39.3 & 24.8 & $\mathrm{PO}, \mathrm{PF}, \mathrm{II}$ \\
\hline 63 & İncesu Spring Water & $36^{\circ} 47.598^{\prime}$ & $036^{\circ} 30.837^{\prime}$ & 427 & 16.3 & 7.67 & 55.2 & 5.15 & 484.6 & 0.28 & 0.378 & 36.2 & 33.5 & \\
\hline 64 & Çakall1-Topboğazı Pond & $36^{\circ} 27.003^{\prime}$ & $036^{\circ} 16.203$ & 180 & 26.8 & 8.47 & 7.66 & 96.3 & 417.7 & 0.19 & 0.262 & 30.5 & 61.5 & $\mathrm{HI}$ \\
\hline 65 & Serinyol Creek & $36^{\circ} 22.080^{\prime}$ & $036^{\circ} 11.426^{\prime}$ & 177 & 24.7 & 7.86 & 5.36 & 67 & 765 & 0.37 & 0.500 & 32.0 & 49.1 & II, PO \\
\hline
\end{tabular}


(Appendix continued)

\begin{tabular}{|c|c|c|c|c|c|c|c|c|c|c|c|c|c|c|}
\hline St. No & St. Name & Latitude N & Longitude E & El. & $\mathbf{T w}$ & $\mathbf{P h}$ & DO & $\mathbf{S}$ & EC & Sal. & TDS & Ta & Moi. & Species codes \\
\hline 66 & Bakras Spring Water & $36^{\circ} 25.598^{\prime}$ & $036^{\circ} 13.259^{\prime}$ & 361 & 22.2 & 8.66 & 8.06 & 92.1 & 844 & 0.44 & 0.578 & 35.0 & 41.2 & NN, HS, IB, HInt, PO \\
\hline 67 & Fengin Stream & $36^{\circ} 25.769^{\prime}$ & $036^{\circ} 08.786^{\prime}$ & 679 & 21.7 & 8.40 & 7.57 & 87 & 608 & 0.30 & 0.403 & 31.9 & 47.9 & NN, HS, PO, ZC \\
\hline 68 & Benli Creek & $36^{\circ} 26.805^{\prime}$ & $036^{\circ} 10.358^{\prime}$ & 591 & 22.7 & 8.44 & 8.29 & 97.1 & 755 & 0.39 & 0.513 & 31.5 & 39.8 & HS, HInt \\
\hline 69 & Sarıseki Stream & $36^{\circ} 39.912^{\prime}$ & $036^{\circ} 12.960^{\prime}$ & 40 & 28.3 & 7.68 & 6.27 & 82.3 & 1555 & 0.73 & 0.949 & 33.5 & 47.5 & PA, HI, CV, HInt \\
\hline 70 & Büyükdere Creek & $36^{\circ} 31.837^{\prime}$ & $036^{\circ} 02.383^{\prime}$ & 23 & 28.5 & 8.13 & 1.56 & 19.2 & 1335 & 0.62 & 0.812 & 39.3 & 44.4 & \\
\hline
\end{tabular}

